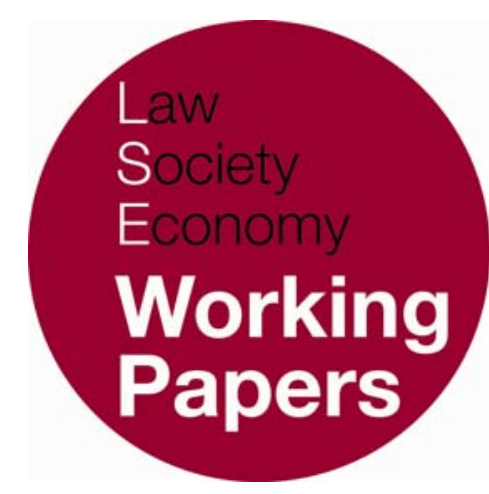

\title{
International Economic Governance and Human Rights Accountability
}

\author{
Margot E. Salomon \\ LSE Law, Society and Economy Working Papers 9/2007 \\ London School of Economics and Political Science \\ Law Department
}

This paper can be downloaded without charge from LSE Law, Society and Economy Working Papers at: www.lse.ac.uk/collections/law/wps/wps.htm and the Social Science Research Network electronic library at: http://ssrn.comabstract=1013505.

(C) Margot E. Salomon. Users may download and/or print one copy to facilitate their private study or for non-commercial research. Users may not engage in further distribution of this material or use it for any profit-making activities or any other form of commercial gain. 


\title{
International Economic Governance and Human Rights Accountability
}

\author{
Margot E. Salomon*
}

\begin{abstract}
The focus on development and poverty reduction by the World Bank and the International Monetary Fund has increased the scope, and opportunity, for these influential international financial institutions to consider the human rights implications of their policybased operations. Some notable advances have been made, such as greater attention by the Bank to the links between securing human rights and economic growth. Still, the negative impact these institutions themselves may have on the exercise of basic socio-economic rights by people in borrowing countries, due to the particular policies they pursue, has not been acknowledged. Given the functioning of international economic governance today it is necessary to consider the human rights accountability, not just of the developing states, but of international actors that influence the direction of their social and economic policies.
\end{abstract}

\section{INTRODUCTION}

While the resources of the World Bank and International Monetary Fund (IMF) represent only a fraction of the total flow of capital, ${ }^{1}$ these public international financial institutions (IFIs) are highly influential development financiers for developing countries. Through the loans, grants and guarantees of the World Bank Group, to the development and implementation of global debt relief initiatives and the jointly assessed poverty reduction strategy papers (PRSPs) which provide the operational basis for concessional lending to low-income countries, ${ }^{2}$ they

\footnotetext{
* Lecturer, Centre for the Study of Human Rights and Law Department, London School of Economics and Political Science. M.E.Salomon@1se.ac.uk. An earlier version of this paper was presented at a conference on Accountability for Human Rights Violations of International Organizations (Brussels, March 2007), convened by the Editorial Committee of the journal Human Rights and International Legal Discourse and the Belgian Branch of the International Law Association. I thank the participants for their insights on this subject, and gratefully acknowledge the valuable comments provided by Peter Townsend on a draft of this paper, which will be published in M.E. Salomon, A. Tostensen and W. Vandenhole (eds), Casting the Net Wider: Human Rigbts, Development and New Duty-Bearers (Antwerp: Intersentia, 2007).

${ }^{1}$ Report of the External Review Committee on Bank-Fund Collaboration (Malan Report) (February 2007) 15.

2 This is undertaken through IMF-World Bank Joint Staff Advisory Notes which are intended to provide staff assessments of the strategies contained in the countries' PRSPs.
} 
exercise pervasive policy influence in recipient countries, ${ }^{3}$ particularly the poorest. ${ }^{4}$ Moreover, the World Bank and IMF indicate to bilateral and other multilateral donors, as well as to private investors, the existence of a suitable investment climate, thereby influencing greatly the availability of other external resource flows. As such, not only do these international financial institutions hold pivotal positions when it comes to developing countries securing sources of finance, through their use of policy-based lending they enforce fiscal and monetary discipline in recipient member states. ${ }^{5}$

Over time the functions of both institutions have undergone significant change, and while formally they may maintain discrete mandates and distinct areas of expertise and focus, today the division of labour between them is blurred, with their work having become 'inherently linked'. ${ }^{6}$ While the World Bank is a development institution it is primarily a financial institution, for example, also making decisions about the investment of the limited (domestic) public resources available. ${ }^{7}$ The IMF, for its part, has changed from a global monetary organisation and sovereign lender of last resort, preoccupied with maintaining macroeconomic stability, into a development-oriented financial institution. ${ }^{8}$ Both institutions exercise financial and political influence and leverage via loan conditions, which are directed at economic liberalisation. A government's policy space in a poor country that relies on their financial assistance is - as a result of this influence dramatically restricted, with IFI policy decisions having implications for the exercise of basic socio-economic rights by the people in the given country.

Although the policy-making functions of the IFIs occur in areas as varied as monetary supply, removal of trade restrictions, privatisation of state enterprises, safety nets, health, education, agriculture, water, extractive industries, transportation, banking and the judiciary, ${ }^{9}$ there is no satisfactory system of accountability available either to those people directly affected by their policy

${ }^{3}$ See, in particular, K. Raffer, 'International Financial Institutions and Financial Accountability' (2004) 18(2) Ethics and International Affairs 75.

4 As Darrow points out, while the extent of IFI influence varies significantly according to a number of factors such as the particular situation and country, and the type of programme or activity concerned,... ' $[\mathrm{n}]$ one of this is to question the generally superior bargaining position and policy leverage enjoyed by the Bank and the Fund vis-à-vis the lowest per capita GDP client countries'. M. Darrow, Between Light and Shadow: The World Bank, the International Monetary Fund and International Human Rights Law (Oxford-Portland: Hart Publishing, 2003) 56-61.

5 C. Tan, 'Mandating Rights and Limiting Mission Creep: Holding the World Bank and International Monetary Fund Accountable for Human Rights', unpublished conference paper, Accountability for Human Rights Violations of International Organizations (Brussels, March 2007) 1. On file with author.

${ }^{6} \mathrm{n} 1$ above, 6. Moreover, recipient countries can only obtain World Bank support if they already have an agreement with the IMF in place.

${ }^{7}$ R. Dañino, 'The Legal Aspects of the World Bank's Work on Human Rights' Special Report, Human Rights and Development, D. Freestone and J.K. Ingram (guest eds) (2006) 8 Development Outreach 30.

8 See D.D. Bradlow, 'The Changing Role of the IMF in the Governance of the Global Economy and its Consequences', Workshop, New Rules for Global Finance (9 June 2006). Available at http://www.newrules.org/docs/imfreform/bradlow_brown060906.htm.

${ }^{9}$ See G. Saul, 'Transparency and Accountability in International Financial Institutions' in R. Calland and A. Tilley (eds), The Right to Know, the Right to Live: Access to Information and Socio-Economic Justice (South Africa: Open Democracy and Advice Centre, 2002) 3, 6-7; and F. Gianviti, 'Economic, Social and Cultural 
decisions (i.e. people in the recipient states), or to the people of the industrialised countries for the policies enforced - via the expenditure of their tax money through the positions advanced by their representatives within the IFIs. Second, any failures in achieving the overarching objective of poverty reduction, including for the poorest in developing countries, incur no IFI accountability. This is despite the fact that the IFIs are being criticised for enthusiastically pursuing neo-liberal economic reforms that can have grave repercussions on, for example, rights to an adequate standard of living, to food, water, health, education and social security reforms often condemned for serving, in particular, the interests of the dominant industrialised member states of the institutions. ${ }^{10}$ While the Boards of Directors of the IFIs may serve as fora for venting grievances by the borrowing countries, they do not function as effective accountability mechanisms, beginning with the fact that the "concentration of structural power [lies] in the hands of the developed creditor countries', ${ }^{11}$ which is manifest in the system of weighted voting rights. ${ }^{12}$

This chapter addresses the issue of international economic governance and the lack of human rights accountability, approaching the subject in three parts. The first outlines the reasons, and the extent to which, human rights have been given attention by the Bank and Fund respectively, and why human rights are relevant to their policy-based operations. The second sets out to underscore the influence that the IFIs have over developing countries through their adherence to a fixed inter-institutional policy - generally referred to as the Washington Consensus - and the human rights implications of this dominance by external actors. The section highlights the convergence of international economic governance around this particular market-oriented economic model that while often shown to be detrimental to poor countries (and to the exercise of certain human rights within those countries), has given rise to no system of holding to account those international actors responsible for the imposition of policies that often have damaging effects, including the exacerbation of poverty. The third presents legal bases and possible avenues for advancing the human rights accountability of the World Bank and IMF for the negative repercussions of their policy advice on the exercise of socio-economic rights and on poverty reduction, in developing countries. While mechanisms for advancing human rights accountability in this area may take various forms, they are all underpinned by the

Rights and the International Monetary Fund', in P. Alston (ed), Non-State Actors and Human Rights (Oxford: Oxford University Press, 2005) 135.

${ }^{10}$ See, for example, n 8 above: 'Without structural change, the IMF will always adopt policies that are heavily biased towards the interests of its key supplier member states', and n 4 above, 211: 'It is simply not realistic to expect the dominant industrialised members - whose interests have been so well served by the IFIs' energetic promotion of the neo-liberal paradigm - to abandon conditionality in the wider sense'. 11 R.H. Wade, 'Tighter IMF Accountability? Some Dangers', in B. Carin and A. Woods (eds), Accountability of the International Monetary Fund (Burlington-Hampshire: Ashgate, 2005) 108.

12 Wealthy countries are also criticised for the control they exercise over the World Bank and IMF by maintaining 'a tight grip on the management, mindset, and mandate of each organization'. N. Woods, 'The Globalizers in Search of a Future: Four Reasons why the IMF and World Bank Must Change, and Four Ways they Can', Centre for Global Development Brief (April 2006) 1. 
drive to entrench the right to a remedy for 'victims of development cooperation'. ${ }^{13}$

\section{LOCATING HUMAN RIGHTS IN THE RATIONALES AND MANDATES OF THE IFIS}

The World Bank is overtly, and deliberately, seeking to consider the place of human rights within its work. This evolution has occurred against a backdrop that has seen the Bank's effective, if not legal, mandate evolve in response to a changing world in which it is fully acknowledged that problems - whether of a human, environmental or economic nature - are integrally related. ${ }^{14}$ Sharp distinctions between the national and international realms have in significant ways been collapsed, with particular challenges facing the Bank and Fund today including 'global issues such as the economic implications of global warming, the quest for energy security, demographic pressures and health pandemics'. 15 Functional necessity and experience had resulted in the Bank, over time, 'shift[ing] its lending focus from an almost exclusive concern with discrete development projects to a concern with the general policy environment within which the project must function, [and] funding both general and sector-specific adjustment programs'. ${ }^{16}$ Today, the World Bank concentrates on poverty alleviation, by means of the self-described objective of economic growth with social equity. ${ }^{17}$ These defining elements reflect the Bank's current purposive understanding of 'development', which is no longer limited merely to economic development. ${ }^{18}$

The International Monetary Fund, while largely rejecting the role of human rights as a factor in influencing its mandate, has over time recognised environmental issues, social safety nets and military expenditure as relevant to its work, ${ }^{19}$ and has begun to pay more attention to the structural causes of balance of

\footnotetext{
13 n 3 above, 77.

14 As Bradlow and Grossman point out: 'The IFIs cannot address the problem of poverty or monetary problems of developing countries without considering the issues of refugees, environmental degradation, the capacity of the state to manage effectively and equitably its resources, population policy, and human rights ... . Trade organizations can no longer effectively regulate trade without seeking agreement on environmental issues, labor policy, investment matters, the regulation of intellectual property (which itself raises important cultural rights issues), and the regulation of trade in services (which also raises important monetary, financial, and immigration policy questions)'. D. D. Bradlow and C. Grossman, 'Limited Mandates and Intertwined Problems: A New Challenge for the World Bank and IMF' (1995) 17(3) Human Rights Quarterly 413; n 1 above, 5.

$15 \mathrm{n} 1$ above, 5 .

$16 \mathrm{n} 14$ above, 421. Bradlow and Grossman explain that these changes were spurred by the 'developmental problems of its borrowing countries and by the failure of many Bank-funded projects to perform as expected'.

17 R. Dañino, Legal Opinion on Human Rights and the Work of the World Bank (27 January 2006) [3 and 7]. And further, World Bank, World Development Report 2000-2001: Attacking Poverty (New York: Oxford University Press, 2000); World Bank, World Development Report 2006: Equity and Development (New York: Oxford University Press, 2006).

18 Dañino, n 17 above [7]: 'development ... encompasses broad areas of human development, social development, education, governance and institutions, as well as issues such as inclusion and cohesion, participation, accountability, equity'.

${ }^{19}$ n 14 above, 416 (drawing on IMF surveys).
} 
payments problems and, to some degree, to the social implications in stabilising and adjusting national economies. ${ }^{20}$ Though conceived as a monetary institution with a mandate to ensure the short-term stabilisation of member states' economies, through restructuring it has over time become increasingly involved in long-term development. ${ }^{21}$ This has resulted in closer collaboration between the Fund and the World Bank with regard to the development agenda and has led to a near convergence of practice, inviting greater visibility for human rights. The IMF's joint involvement alongside the Bank in the poverty reduction strategy process through the Heavily Indebted Poor Country Initiative since 1999 exemplifies this shift from a focus on purely monetary matters to wider developmental concerns, as does its professed commitment, along with the Bank, to seeing that the Millennium Development Goals (MDGs) are achieved. And as the Bank's former General Counsel noted when endorsing the position of the United Nations (UN) High Commissioner for Human Rights on the matter: 'This conception of the alleviation of poverty has an especially strong human rights dimension'. ${ }^{22}$ However, despite a noteworthy merging of their roles, and the conclusions of repeated reviews that 'collaboration between the Bank and the Fund is essential if each institution is to fulfil its mandate and serve the interests of its members', ${ }^{23}$ no joint position on human rights has been established, and no explanation has been provided as to how the Bank is able 'to review its role with a view to making a more explicit link between human rights and [its] work', and to advocate that 'poverty itself is a fundamental denial of human rights' 24 while the IMF does not.

The mutually reinforcing links between human rights and development, and indeed the contemporary definition of 'development' that incorporates a wide range of non-economic concerns, provides an important basis for advocating that the IFIs must contend with human rights. Yet this submission provides only one basis for arguing that human rights concerns should be integrated into the work of the IFIs. The requirement that the IFIs respect human rights is not linked solely to the fact that today human rights are increasingly understood as falling within their competences, but also that they respect human rights, and are accountable for their violation, wherever their mandates direct them. A rights-based approach to globalisation seeks to place international human rights standards and principles at the centre of international economic affairs and to have them successfully inform all cooperative endeavours that may impact on their exercise. ${ }^{25} \mathrm{~A}$ point of departure is to offer a human rights framework of analysis and policy construction that identifies rights violations and potential violations and is neutral in the sense

20 ibid, 420-421

21 B. Rajagopal, 'Crossing the Rubicon: Synthesizing the Soft International Law of the IMF and Human Rights' (1993) 11(1) Boston University International Law Journal 92.

22 Dañino, n 17 above, [7].

23 n 1 above, 18.

${ }^{24} \mathrm{~J}$. Wolfensohn, Note from the President of the World Bank to the $71^{\text {st }}$ meeting of the Joint Ministerial Development Committee of the Board of Governors of the Bank and the Fund, DC2005-0005 (12 April 2005) [49].

25 M. E. Salomon, Global Responsibility for Human Rights: World Poverty and the Development of International Law (Oxford: Oxford University Press, 2007). 
that it allows open investigation of, and debate about, the strength of various alternative solutions.

Yet the IMF, for example, has taken the public position that trade-offs derived from the allocation of resources require only that the concerns of the 'losers' are addressed as best as can be, ${ }^{26}$ while it has been criticised by its own Independent Evaluation Office for having done 'little to address poverty reduction and income distributional issues despite institutional rhetoric to the contrary', and for blocking the use of available aid through 'overly conservative macroeconomic programmes'. ${ }^{27}$ The discredited 'structural adjustment' was formally replaced by the end of the 1990s with 'poverty reduction strategies', which were to set out a new way of working grounded in the poverty reduction strategy process, with programmes based on country-owned measures geared to poverty reduction and growth. However, factors including weakening consensus in the Board and a staff professional culture strongly focused on macroeconomic stability meant 'the Fund gravitated back to business as usual'. ${ }^{28}$ The World Bank's auditing arm, the Independent Evaluation Group, reported in 2006 that the Bank has focused too narrowly on economic growth, leaving unemployment and poverty rates to stagnate or worsen. ${ }^{29}$ Today, controversial IFI-imposed ceilings on government expenditure that are inconsistent with fundamental human rights continue, ${ }^{30}$ as do cost recovery mechanisms, such as user fees for access to education and for medicines and medical services. The former UN Special Rapporteur on the Right to Education highlighted in a 2006 global report that for 'development banks education figures as an expenditure item to be decreased to diminish fiscal deficit. This conflicts with the requirement in international human rights law to prioritize the right to education in budgetary allocations so as to ensure (at least) free and compulsory education for all children.' ${ }^{31}$ A 2002 World Bank survey showed that there were school fees in 97 percent of the 79 countries surveyed. These were

${ }^{26}$ High-Level Task Force on the Implementation of the Right to Development (1 st session, 2004). Notes on file with author. See, further, M. E. Salomon, 'Towards a Just Institutional Order: A Commentary on the First Session of the UN Task Force on the Right to Development' (2005) 23(3) Netherlands Quarterly of Human Rights 428-432.

27 International Monetary Fund Independent Evaluation Office, An Evaluation of the IMF and Aid to SubSabaran Africa (March 2007) [ii] (the evaluation covers the period 1999-2005, when the PRSP was introduced and the IMF transformed its Enhanced Structural Adjustment Facility into the Poverty Reduction and Growth Facility).

28 ibid, [v].

29 World Bank Independent Evaluation Group, Annual Review of Development Effectiveness 2006: Getting Results (Washington, World Bank, 2006) as cited in 'Bank focuses on growth often leaves poor behind', Inter-Press Service (7 December 2006).

${ }^{30}$ n 27 above, [42]: The IMF Poverty Reduction and Growth Facility conditionality on the public sector wage bill has resulted in spending ceilings that 'are not not first-best solutions and clearly have sometimes had unintended consequences. Possible side-effects range from the limited ability to absorb immediately and spend unanticipated aid inflows for the hiring of teachers and nurses to the proliferation of fringe benefits and other nontransparent forms of remuneration designed to circumvent the ceilings'.

${ }^{31}$ K. Tomasevski, The State of the Right to Education Worldwide: Fee or Free Global Report 2006 (August 2006) xiv. Available at www.katarinatomasevski.com. 'Intergovernmental actors would place themselves on a collision course with much of their influential constituency if they were to tackle denials of the right to education. The biggest shareholder, the USA, would necessarily become a target of critique. So would the 
imposed even where the borrower's laws mandated primary education to be free..$^{32}$ The incomplete data were attributed to the fact that the fees may be formally unconstitutional. ${ }^{33}$ The UN Special Rapporteur on the Right to Health has voiced his concern that, in many countries, user fees tend to exclude the poor and other marginalised groups from essential services and that this may be inconsistent with the right to health, ${ }^{34}$ while further highlighting the fact that 'nationally'-owned poverty reduction documents must be endorsed by the IMF and the World Bank if they are to attract international programme support from donors and the United Nations. The Special Rapporteur recommended that when the IFIs assess and make recommendations on country-owned strategies, including Joint Staff Advisory Notes, they take into consideration the developing states' national and international human rights obligations. ${ }^{35}$

The responsibility incumbent upon the IFIs is not solely to ensure that the policies they advance do not compel a developing state to breach its human rights obligations but is due to the fact that international actors may possess their own (external) human rights duties. Any measures impacting negatively on, for example, the right to education or the right to health may not only be incompatible with the achievement of the MDGs related to education and health to which the IFIs subscribe, but are also reflective of non-compliance by states parties to the UN International Covenant on Economic, Social and Cultural Rights (ICESCR) ${ }^{36}$ and to the UN Convention on the Rights of the Child (CRC). ${ }^{37}$ Breaches could include, for example, failure to have adjusted spending caps and to have supported financially the removal of user fees through the mobilisation of resources to ensure access to basic rights and the accompanying administrative infrastructure to deliver those rights. This would constitute prima facie a violation of states parties' obligations of international cooperation (whether acting as members of the IFIs or bilaterally) under those human rights treaties. ${ }^{38}$ Additionally, those states engaging

World Bank and its sister institution, the International Finance Corporation (IFC), which is expanding private education.' (xxiv).

32 R. Kattan and N. Burnett, User Fees in Primary Education (World Bank, 2004) 9-10. Available at www.worldbank.org/education/pdf/EFAcase_userfees. Subsequently, a number of developing countries have introduced free primary education with World Bank funding.

33 ibid, 9. This report remarks that the World Bank is abolishing user fees, while Tomasevski emphasises that the World Bank's endorsement of free primary education had been included in its education sector policy paper in 1980 but not in its 1999 education strategy, highlighting in 2006 the fact that there 'has been no in-house review of the impact of the World Bank's support for illegal charging of school fees as yet'. n 31 above, 2 .

34 P. Hunt, Report of the Special Rapporteur on the Right to the Highest Attainable Standard of Physical and Mental Health: Mission to Mozambique, UN Doc. E/CN.4/2005/51/Add.2, [49-50].

35 ibid, [77].

36 International Covenant on Economic, Social and Cultural Rights (1966), entered into force 3 January 1976, GA res. A/RES/2200A (XXI), 993 UNTS 3. There were 156 states parties to the ICESCR at 19 April 2007.

37 Convention on the Rights of the Child (1989), entered into force 2 September 1990, General Assembly res. A/RES/44/25, annex 44, UN GAOR Supp. (No. 49), 167, UN Doc. A/44/49 (1989). There were 193 states parties to the CRC at 19 April 2007.

${ }^{38}$ For a detailed consideration of the sources and content of human rights obligations of international cooperation, see n 25 above. ICESCR Art. 2(1): 'Each State Party to the present Covenant undertakes to take steps, individually and through international assistance and co-operation, especially economic and 
internationally that have promoted the cost recovery mechanisms leading to basic human rights being compromised, do so in violation of their negative external state obligation to 'respect' the right to education or the right to health in developing countries. ${ }^{39}$ We return in the third section below to look more carefully at the issue of the accountability of the IFIs and of their powerful member states.

The international policy framework that informs economic management may be growing increasingly sensitive to the social consequences of liberalisation, privatisation and deregulation - perhaps representing a shift from a 'Washington Consensus' to a 'post-Washington Consensus' ${ }^{40}$ (or perhaps a return to a preWashington consensus). ${ }^{41}$ Yet it remains an economically driven process that proceeds on the primary principles of private property and uninhibited market forces, ${ }^{42}$ on a strange mix of a doctrine of liberalised markets, ${ }^{43}$ protectionism ${ }^{44}$

technical, to the maximum of its available resources, with a view to achieving progressively the full realization of the rights recognized in the present Covenant by all appropriate means, including particularly the adoption of legislative measures'; CRC Art. 4: 'States Parties shall undertake all appropriate legislative, administrative, and other measures for the implementation of the rights recognized in the present Convention. With regard to economic, social and cultural rights, States Parties shall undertake such measures to the maximum extent of their available resources and, where needed, within the framework of international co-operation'. 'The Committee [on Economic, Social and Cultural Rights] notes that the phrase "to the maximum of its available resources" was intended by the drafters of the Covenant to refer to both the resources existing within a State and those available from the international community through international cooperation and assistance.' CESCR, General Comment No. 3 (Art. 2(1)) The Nature of States Parties Obligations, UN Doc.E/1991/23, annex III (1990) [13]. Maximum available resources at the international level are equated with the globally endorsed 0.7 percent of GNI in official development assistance, which now represents an objective standard, and its phased achievement is used by the CESCR as a yardstick to measure whether a developed country is in fact taking steps to the maximum of its available resources.

39 See W. Vandenhole, A Partnership for Development: International Human Rights Law as an Assessment Instrument, Submission to the 2nd session, of the UN High-Level Task. Force on the Right to Development (November 2005) [19]. At www.ohchr.org/english/issues/development/taskforce.htm.

40 Maxwell refers to a 'current meta-narrative' that has replaced the post-Washington Consensus. 'It emphasises the Millennium Development Goals, as an over-arching framework, and lays out the link between the MDGs, nationally owned poverty reduction strategies, macro-economic policy (including trade), effective public expenditure management, and harmonised aid in support of good governance and good policies. It also recognises the concern for security and poorly performing countries, as well as the international trade and finance agenda. The current meta-narrative can be improved, by paying more attention to rights, equity and social justice, to the problems of "infant economies", and to issues of aid policy and aid architecture'. S. Maxwell, The Washington Consensus is Dead! Long Live the Meta-Narrative, Overseas Development Institute, Working Paper 243 (2005) v.

${ }^{41}$ B. Bull, A. M. Jerve and E. Sigvaldsen, The World Bank's and the IMF's use of Conditionality to Encourage Privatization and Liberalization: Current Issues and Practices, Report Prepared for the Norwegian Ministry of Foreign Affairs, background document for the Oslo Conditionality Conference (November 2006) 28.

42 ibid, vi; UN Research Institute for Social Development (UNRISD), 'The Sources of Neoliberal Globalization', Report of UNRISD Seminar on Improving Knowledge on Social Development in International Organizations II (2002) 4.

43 Policy advice and assisting in the preparation and elaboration of policy 'have generally been geared towards privatization and liberalization, and little effort [by the World Bank or IMF] has been made to elaborate policy alternatives'. n 41 above, vii.

44 'What are the costs of trade protectionism for the developing world? A number of studies have tried to assess this. To take one example, the World Bank has considered the impact of a "pro-poor" trade liberalization scenario. This scenario involves only tariff reductions and agricultural subsidies reform. The welfare gains to developing countries of this liberalization scenario are estimated to be over US $\$ 250$ billion in 2003 prices. This is four times the value of foreign aid. ... The possibility of exports helping to alleviate poverty is significantly curtailed by trade protectionism in rich countries. This occurs in the form 
and vastly unequal power. In the World Bank's own words: 'Developing countries face massive challenges in influencing the global rules and processes that determine outcomes, which matter greatly to the well-being of their citizens'. ${ }^{45}$ While the goal of bilateral and multilateral development agencies is now being expressed in terms of poverty reduction ${ }^{46}$ and 'pro-poor' growth, ${ }^{47}$ serious concerns that economic efficiency is prioritised over social equity remain. ${ }^{48}$ The World Bank's own auditing arm, the Independent Evaluation Group, recently confirmed that the Bank's projects had not adequately reduce poverty levels in borrowing nations over the past five years, ${ }^{49}$ with the Fund's Independent Evaluation Office similarly concluding that 1999-2005 'was a time of improving macroeconomic performance in a number of Sub-Saharan African countries, with increasing growth rates and decreasing inflation rates - but almost no change in the share of the population living in poverty. ${ }^{50}$

Contemporary strategies for reducing poverty and inequality exist in tension with the poverty and inequality logically implied by free market forces. Globalisation may be a positive sum game in the aggregate but it is one that produces both winners and losers, as the World Bank formally recognises. ${ }^{51}$ Notions of aggregate benefit (a rising tide that lifts all boats) and the collective good that the free market espouses, work against greater equality, benefiting those who have skills valued by the market while further marginalising the poorest and those already politically disadvantaged. 52 Still, the neo-liberalism traditionally embraced by the World Bank and IMF, and consistent with the World Trade Organization (WTO) project of free trade, traditionally favours 'slimming the state' - reducing the size and growth of public expenditure and divesting the state of a number of its functions - and related objectives, notably encouraging

of tariffs, subsidies, quotas, standards, and regulations. ... Rich-country protectionism poses a significant barrier to poverty alleviation, not to mention the overall participation of the developing world in the global economy.' I. Goldin and K. Reinert, Globalization for Development: Trade, Finance, Aid, Migration, and Policy (Washington-London, World Bank-Palgrave MacMillan, 2006) 66 and 75.

45 World Bank, World Development Report 2006, n 17 above, 68.

${ }^{46}$ See A. M. Jerve, 'Social Consequences of Development in a Human Rights Perspective: Lessons from the World Bank', in I. Kolstad and H. Stokke (eds), Writing Rights (Bergen: Fagbokforlaget, 2005) 100.

47 See for example, Pro-Poor Growth in the 1990's: Lessons and Insights from 14 Countries (Washington: World Bank, 2005).

48 '[T] he report [of the World Bank's Independent Evaluation Group, 2006] pointed out how exportoriented and privatisation dependent economies tend to suffer when growth does occur because the gains go to very few people'. A commentator remarked that: 'Language [in the report] is couched carefully so as not to address directly the failures of the now much-discredited poverty-creating, "Washington Consensus" structural adjustment policies, as liberalisation, privatisation and other adjustment measures are still being placed on loans by these institutions'. 'Bank focuses on growth often leaves poor behind', $\mathrm{n}$ 29 above.

49 ibid.

50 n 27 above, [2]. On IMF inflation targets and poverty reduction, see, further, D. Goldsbrough, 'The IMF and Constraints on Spending', International Poverty Centre, No. 35 (May 2007).

51 D. Leipziger and M. Spence, 'Globalisation's Losers Need Support', Financial Times (15 May 2007). (Leipziger is a vice-president at the World Bank).

52 J. Donnelly, Universal Human Rights: Theory and Practice (Ithaca NY: Cornell University Press, 2003) 201; UNRISD, n 42 above, 3. Jeffrey Sachs similarly notes that, 'if you start poor ... the market is trained to ignore you'. J. Sachs, The End of Poverty: Economic Possibilities for Our Time, Transcript, Carnegie Council on Ethics and International Affairs (30 March 2005). www.carnegiecouncil.org. 
privatisation and moving public services closer to the market model in requiring users to pay a share of the costs of running the services. ${ }^{53}$ These measures are often compulsory, despite resistance by recipient states, with human rights-holders left to direct claims to their enfeebled governments as duty-bearers under the relevant human rights treaties, while the IFIs, wearing their 'non-state' actor hats, are able to dismiss the contention that they are in any way implicated in the human rights violations that may ensue, by claiming to possess no legal obligations in the area of socio-economic rights ${ }^{54}$ (a point to which we return below). This erosion of national authority undermines reconciliation between the poverty and inequality that inhere in the free market and the more egalitarian and redistributive public welfare implied in all meanings attached to the 'democratic' state. 55 The soft law Declaration on the Right to Development, in providing that 'States have the right and the duty to formulate appropriate national development policies that aim at the constant improvement of the well-being of the entire population and of all individuals, on the basis of their active, free and meaningful participation in development and in the fair distribution of the benefits resulting therefrom', seeks to provide a normative basis for the regulation of this fundamental disjuncture in the attribution of responsibility. ${ }^{56}$ The formulation recognises that, in addition to its own domestic human rights obligations in this area, the developing state can assert the right of its people to development against other states and the international community. ${ }^{57}$

There is a trend, though, toward the Bank recognising codified human rights - both civil and political, and economic, social and cultural - as obligations of the borrowing state and as rights belonging to the people within the member states with which they work. There is greater awareness, for example, that investment in health and education, especially for women, is a precondition for economic

${ }^{53}$ H. Stokke, 'What is Left of State Responsibility?: Turning State Obligations into State Responsibility in the Field of Economic, Social and Cultural Rights', in M. Scheinin and M. Suksi (eds), Human Rights in Development, Yearbook 2002 (Leiden/Boston-Oslo: Martinus Nijhoff Publishers and Nordic Human Rights Publications, 2005) 43, 48 et seq. Here Stokke draws on the work of P. Self, Government by the Market? (London: MacMillan, 1993).

${ }^{54}$ In the words of the former IMF General Counsel: ‘... [T] he Fund and the Bank saw themselves (and continue to see themselves) as international organizations separate from their members, and governed by their respective charters.' Gianviti, n 9 above, 115.

55 This problem is identified in the literature and summed up in a recent UK Policy Paper on conditionality, which highlights the negative impact both bilateral and multilateral donors are having on democratic governance in recipient countries as a result of developing countries being answerable to their donors rather than to their constituents. Partnerships for Poverty Reduction: Rethinking Conditionality, UK Policy Paper (March 2005). A corollary is that policy-makers can escape responsibility for their actions by attributing unpopular policies to the IFIs or other agencies. G. Standing, Beyond the New Paternalism: Basic Security as Equality (London, Verso, 2002) as cited in Stokke, n 53 above, 49.

56 Declaration on the Right to Development, GA res. A/RES/41/128, 4 Dec. 1986, annex 41 UN GAOR Supp. (No. 53) 186, UN Doc. A/RES/41/53 (1986), Art. 2(3).

57 On the right to development and the state as the international dimension of peoples, see J. Crawford, 'Some Conclusions', in J. Crawford (ed), The Rights of Peoples (Oxford, Clarendon Press, 1988) 167; L. A. Obiora, 'Beyond the Rhetoric of a Right to Development', 18 Law \& Policy 3-4 (1996) 369; A. Orford, 'Globalization and the Right to Development' in P. Alston (ed), Peoples' Rights (Oxford: Oxford University Press, 2001) 137; n 25 above. As the Declaration affirms in its Preamble: 'the right to development is an inalienable human right and [that] equality of opportunity for development is a prerogative both of nations and of individuals who make up nations'. Emphasis added. 
growth and poverty reduction. ${ }^{58}$ There is work being done within the Bank on empirically verifying the causal link between civil and political rights (improved governance') and higher incomes ('socio-economic and developmental rights'). ${ }^{59}$ In 2006 the Bank established a Justice and Human Rights Trust Fund to further the mainstreaming of human rights through a variety of projects and via research and training. ${ }^{60}$ By relying on a narrow and somewhat anachronistic description of itself as exclusively a financing institution, the IMF, for its part, assumes it is shielded from having to confront these constructive (instrumental) links between human rights and development, thereby justifying far less engagement with human rights generally. ${ }^{61}$

This focus on human rights is deemed important to the Bank - and is justified by the Bank - in that it recognises that social and political as well as environmental factors may affect economic growth. ${ }^{62}$ These factors that may impact on the Bank's 'investments and other activities' have thus moved from constituting 'political considerations', whereby they would fall foul of the prohibition on political activities under the Bank's Articles of Agreement, to being recognised as constituting 'economic considerations', thereby being deemed of legitimate concern to the Bank. ${ }^{63}$ Interestingly, while the formal legal constraints are more restrictive in the case of the Bank's Articles of Agreement than those of the IMF, the Bank has been far more willing to interpret the prohibition in a manner that recognises the interdependence between the protection of human rights and sustainable economic and human development.

While the Bank and its officers are precluded (in theory) from intervening in the 'political affairs' of its member countries or from being influenced by their 'political character', and are required to take only 'economic considerations' into account, ${ }^{64}$ the IMF's Articles of Agreement require it to 'respect the domestic

58 n 41 above, 28.

59 D. Kauffman, 'Human Rights, Governance and Development,' Special Report, Human Rights and Development, D. Freestone and J. K. Ingram (guest eds), 8 Development Outreach (Washington: The World Bank Institute, October 2006) 15.

${ }^{60}$ But note that over the years the Bank has established multiple trust funds financed by member states such as the like-minded donors (Nordics, Netherlands, Canada). These funds are financed over and above the regular subscriptions by the member states and have been seen as an attempt to soften the sharp neo-liberal profile of the Bank. Critics suggest that they are mere window dressing.

${ }^{61}$ The former IMF General Counsel remarks: 'The Fund is a monetary agency, not a development agency. While its mandate and policies have evolved over time, it remains a monetary agency, charged with the responsibility to maintain orderly exchange rates and a multilateral system of payments free of restrictions on current payments'. Gianviti, n 9 above, 137.

62 Dañino, 17 above, [10].

63 Where the Bank is involved in lending or advising on development policy issues a comprehensive understanding of the country context is critical: this could include knowledge of a wide range of relevant social, institutional and political factors, including human rights. It is therefore consistent with the Articles that the decision-making processes of the Bank incorporate human rights and any other relevant input which may have an impact on its economic decisions.' Dañino, n 17 above, [12]; see also R. Dañino, 'The Legal Aspects of the World Bank's Work on Human Rights: Some Preliminary Thoughts' in P. Alston and M. Robinson (eds), Human Rights and Development: Towards Mutual Reinforcement (Oxford: Oxford University Press, 2005) 516-517.

64 Articles of Agreement of the International Bank for Reconstruction and Development, 27 December 1945, 60 Stat. 1440, TIAS No. 1502, 2 UNTS 134 (as amended 1965 and 1989) Art. IV, Section 10; Articles of Agreement of the International Development Association, 26 January 1960, 11 UST 2284, 
social and political policies of members, and in applying these principles [general obligations of members pursuant to Article IV(1)] the Fund shall pay due regard to the circumstances of members'. ${ }^{65}$ While this Article has been interpreted as requiring the IMF to refrain from interfering in domestic political affairs for the purposes of rejecting the human rights implications of its work, ${ }^{66}$ an alternative reading is that 'any IMF member has the right to choose policies that differ from the fairly uniform IMF prescription usually summed up as the Washington Consensus'. ${ }^{67}$ Moreover, on a strict reading of the terms of the IMF's Articles, it could be argued that a greater onus is placed on the IMF than the Bank to ensure that none of the policies it imposes on borrowing countries impact negatively on those policies geared towards improving social well-being (i.e. human rights), nor serve to undermine the ability of borrowing states to fulfil their domestic and international human rights obligations.

Findings indicate, however, that politics in fact play a far more considerable role than the mandates of the IFIs would suggest. The approved approach of late favouring 'national ownership' of the Bank and Fund poverty reduction programmes is undermined by weaknesses in participatory processes; extensive dependence on IFIs in the elaboration of policies; lack of 'policy space' and analysis of policy alternatives; and the IFI's seeking to promote their 'own cause'. ${ }^{68}$ Significantly, IFI policy choices are not de jure inconsistent with human rights standards, since compliance with obligations undertaken in the realm of socio-economic rights does not require adherence to any particular economic system. International human rights law is neutral in that it is not predicated exclusively on the desirability of one economic (or political) model or another. However, it does contain both principles and standards that seek to ensure that the methods for achieving economic growth are just and that its benefits are fairly distributed. ${ }^{69}$ This implies, as a start, the construction of basic services and other minimum entitlements for universal access and gain, and imposes constraints on the endorsement of extreme economic and social models. It also requires that any person or group who is the victim of a violation of a right 'have access to effective judicial or other appropriate remedies at both national and international levels'. As the UN Committee on Economic, Social and Cultural Rights (CESCR) has made clear, victims are 'entitled to adequate reparation, which may take the form of restitution, compensation, satisfaction or guarantees of non-repetition ... '. ${ }^{70}$

TIAS No. 4607, 439 UNTS 249, Art.V, Section 6; Articles of Agreement of the International Finance Corporation, 25 May 1955, 264 UNTS 117; UKTS 37(1961), Cmnd 1377; TIAS 3620; UST 2197 (as amended effective 1993) Art. III, Section 9.

65 Articles of Agreement of the International Monetary Fund, 27 December 1945, 60 Stat. 1401, 2 UNTS 39 (as amended 1969, 1978, 1992) Art. IV, Section 3(b). Similar provisions disallowing objections based on member states' domestic social or political policies are restated at Arts. XXXI Schedule C(4) and (7). ${ }^{66}$ Gianviti, n 9 above, 129; and see Bradlow and Grossman, n 14 above, 432.

${ }^{67} \mathrm{n} 3$ above, 66.

${ }^{68} \mathrm{n} 41$ above, vii.

${ }^{69}$ CESCR, General Comment No. 3, n 38 above, [8].

70 CESCR, General Comment No. 12 (Article 11) The Right to Adequate Food, UN Doc. E/C.12/1999/5 [32]. See also CESCR, General Comment No. 9, The Domestic Application of the Covenant, UN Doc. E/C.12/1998/24. 
While the political prohibitions in the mandates of the IFIs, importantly, are meant to limit undue influence being exercised by these external actors and to ensure impartiality from ideology, as Clapham has pointedly remarked: 'to turn this attempt to constrain the potential for ideological partiality by the Bank into an assertion that it is illegitimate for the IMF or the Bank to consider the human rights implications of its own actions is to turn the prohibition inside out. The prohibition was, in a sense, designed to protect a human right, the right to selfdetermination: the right to choose one's economic and political system. Such a prohibition can hardly serve to create a general impunity from human rights accountability for the international organization.' 71 Embracing a neo-liberal approach to economic and social policy rather than more redistributive models the former representing the agenda that the IFIs are traditionally known to favour - and then selectively imposing the preference on borrowing countries, is nothing if not reflective of a political ideology. Indeed, part of the reason for including the political prohibition when the Bretton Woods institutions were founded was to ensure that these new organisations not be used to promote the influence of the capitalist countries over the Communist bloc, or vice versa. ${ }^{72}$ Insofar as impartiality was an objective of the drafters, not only has the political prohibition failed to ensure external policy prescriptions that are free from particular economic dogma but they have served as a legal premise for the exclusion of human rights considerations despite their relevance.

But these foundational documents are not seen as static. Open breaches of the IMF's Articles of Agreement in certain areas - Raffer, for example, refers to forcing member countries to liberalise capital accounts (a decision implicated in the Asian financial crisis of 1997) - resulted in talk of retroactive amendment of the Articles of Agreement to allow for what the IMF had already been doing anyway. ${ }^{73}$ The World Bank Group's International Bank for Reconstruction and Development (IBRD), for its part, moved from financing projects such as dams and harbours, to structural adjustment lending programmes, even though its Articles stipulate that loans 'shall, except in special circumstances, be for the purposes of specific projects .... ${ }^{74}$ Its International Development Association (IDA), charged with interest-free lending to the poorest countries, has the same restriction within its Articles. ${ }^{75}$ In examining the objectives of the Bank's Articles of Agreement against the backdrop of the 'current international legal regime and the evolving understanding of development', a former General Counsel of the Bank has recently argued that it is indeed this 'purposive approach [that] has

\footnotetext{
71 A. Clapham, Human Rights Obligations of Non-State Actors (Oxford: Oxford University Press, 2006) 143144.

72 n 4 above, 168-169.

73 n 3 above, 65 .

74 IBRD Articles of Agreement, n 64 above, Art. III, Section 4(vii).

75 IDA Articles of Agreement, n 64 above, Art. V(b).
} 
enabled the Bank to define its current mandate as poverty alleviation notwithstanding that the Articles make no explicit reference to poverty'. ${ }^{76}$

Thus the important observation, firmly placed in the public domain by the Bank recently, i.e. that 'political considerations can have economic effects' and that '[i]t is therefore consistent with the [Bank's] Articles [of Agreement] that the decision-making processes of the Bank incorporate human rights and any other relevant input which may have an impact on its economic decisions', is significant and consistent with the approach to treaty interpretation the IFIs seem so far to have taken. Yet, as mentioned, this important determination by the former General Counsel (that human rights fall within the Bank's competence) tables only one part of the equation.

While the IFIs were not meant to intervene in members' economies, they do. ${ }^{77}$ And while an obligation not to 'interfere' politically in the domestic affairs of their recipient countries is not only understandable, but in fact welcome in an era that is characterised by a dramatic diminution in domestic autonomy limiting the ability particularly of poorer and less influential states independently to decide their own economic and social policies, 'interference' (read: influence) by international economic actors is in fact ubiquitous. As such, the concern regarding the World Bank (and the IMF) in relation to human rights pertains not only to the relevance of human rights to their economic decisions but to the impact of their economic decisions on human rights. Put differently, human rights considerations are important not solely because of their instrumental value in increasing the likelihood of better economic outcomes but because, properly considered, they should shape the processes and outcomes of economic decisions in order to render them consistent with international human rights standards. Of course, these rights have been codified and endorsed by a majority of states since the terms of reference of the Bretton Woods institutions were first approved in the 1940s.

This line of thinking likewise holds that there is a difference between the Bank taking on human rights in an effort to facilitate the human rights responsibilities of its members through the provision of support in giving effect to their human rights obligations (as described above), ${ }^{78}$ and accountability for the impact on human rights of the World Bank (or indeed the IMF) itself for its

76 Dañino, n 17 above, [6]. On the Bank's interpretative approach see, further, I.F.I. Shihata, 'Interpretation as Practiced at the World Bank', in The World Bank Legal Papers (Boston: Martinus Nijhoff, 2000) xliv-xlv.

77 The British economist John Maynard Keynes was a central figure in the creation of the Bretton Woods institutions, advocating for the creation by the big countries of 'a giant fund from which countries in demonstrable financial adversity could draw - up to a sizeable minimum level - without strings. Up to that minimum level they would not have to justify their policies. ... What materialised was a pale shadow of Keynes' intentions'. P. Townsend, 'Human Rights, Transnational Corporations and the World Bank', in P. Townsend and D. Gordon (eds), World Poverty: New Policies to Defeat an Old Enemy (Bristol: The Policy Press, 2002) 357. Raffer reminds us that the IMF was established to provide unconditional emergency resources, and not to finance any programmes. $\mathrm{n} 3$ above, 74 .

78 A. Palacio, 'The Way Forward: Human Rights and the World Bank', Special Report, Human Rights and Development, D. Freestone and J.K. Ingram (guest eds), (2006) 8 Development Outreach 36; Dañino, n 17 above, [19]. 
economic policy prescriptions in borrowing countries. These would be one and the same if the IFIs, in fact, played a supporting role but, despite a greater focus on national ownership, externally imposed policies were the norm and - in no small measure - remain so. That the Bank 'may take any type of human right into account provided there is economic impact or relevance'79 tells us little about the nature of Bank responsibilities to take human rights into account because its economic decisions may impact on them. Recognising 'the role of human rights as legal principles which may inform a broad range of activities, and which may enrich the quality and rationale of development interventions, and provide a normative baseline against which to assess development policies and programmes', as the new General Counsel has recently suggested, ${ }^{80}$ comes closer to locating human rights standards properly within the work of the Bank (and to a certain degree the Fund given its role in development). Yet, even this support for human rights in the work of the Bank does not go nearly far enough towards recognising the role of the Bank/IFIs themselves in contributing to policy-based human rights violations in recipient countries, including with regards to failures in applying policies that are likely to contribute meaningfully to reducing poverty. Nor does it indicate how human rights accountability and redress for the victims of ill-advised economic policies might be addressed within, in particular, the Bank's emerging willingness to engage with these standards, and given the joint work of the IFIs on development, and on the MDGs and poverty alleviation more generally.

In sum, the approach of the World Bank to human rights would seem to be threefold. One approach explains that what the Bank does contributes to the realisation of a range of human rights. This position has been reaffirmed recently in (former Bank president) Wolfensohn's final speech to a World Bank/IMF Development Committee meeting and subsequently reaffirmed in Dañino's legal position paper. ${ }^{81}$ A second approach emphasises the role of the Bank in supporting or facilitating the realisation of the human rights obligations of recipient countries where those obligations relate to Bank projects and policies. As noted above, both Dañino and, in particular, Palacio, the new General Counsel, have focused on this not insignificant aspect. ${ }^{82} \mathrm{~A}$ third approach to human rights focuses on the instrumental relevance of human rights protection and promotion to the making of better economic actors and improved economic development. As is clear, none of these approaches addresses a fourth critical factor: the human

\footnotetext{
79 Dañino, n 17 above, [13]; 'Where violations or non-fulfilment of obligations are at issue and these have an economic impact, the Bank should take them into consideration.' ibid, [20].

80 Palacio, n 78 above, 36.

81 'The Bank's work substantially contributes to the realization of rights of people in a number of areas, such as health, education, gender, participation, accountability, environment, and institutional reform activities, and, above all, the fight against poverty itself as a fundamental denial of human rights. Other Bank activities also contribute to the realization of human rights: these include fighting corruption, increasing transparency and accountability in governance.' n 24 above, [49]; Dañino, n 17 above, [1] (reminding us that this position was affirmed by the Bank in 1998).

82 Although without suggesting that human rights should form the basis for an increase in Bank conditionality or present an obstacle for disbursement or increase the cost of doing business. Palacio, $n$ 78 above, 36 .
} 
rights accountability of international economic actors for their own negative impact on the exercise of basic socio-economic rights by people in recipient member states.

\section{NEGATIVE INTER-INSTITUTIONAL POLICY COHERENCE}

The influence of international economic organisations, the impact of external actors advancing the requirements of a global free market, and the corresponding limits to domestic policy space in developing countries for 'socially desirable purposes' are a contemporary reality under globalisation. ${ }^{83}$

The WTO is the main international economic institution for the regulation of international trade and trade-related issues. Within the organisation, the more powerful members effectively press for the terms under which the opening of markets will take place. The lead international financial institutions - the World Bank and International Monetary Fund - in seeking to achieve coherence with the WTO regime - as is foreseen under the Marrakesh Agreement establishing the $\mathrm{WTO}^{84}$ - influence greatly the domestic policies in borrowing countries that will best serve these market-oriented objectives. Indeed, the IMF's work in trade is rooted in Article I(ii) of its founding Charter, which states that it shall 'facilitate the expansion and balanced growth of world trade'. Trade policy forms a fundamental aspect of the Fund's core macroeconomic agenda, with conditionality related to trade liberalisation found in 80 percent of the Enhanced Structural Adjustment Facility/Poverty Reduction and Growth Facility programmes, and with only 20 percent of borrowing countries never having had any binding conditionalities related to trade imposed by the IMF. ${ }^{85}$ Recent research indicates that the IMF's use of trade conditionality has followed only a slightly different pattern than that of the Bank. ${ }^{86}$ Dañino reminds readers of his Legal Opinion early on that an analysis of the relevance of human rights to the Bank's work is guided by its purposes at Article I of its Articles of Agreement, which include the promotion of private foreign investment and growth of international trade, inter alia, to raise standards of living. ${ }^{87}$ While Article I of IDA's Articles of Agreement, which outline its purposes, makes no specific reference to trade or any other particular model for promoting economic development (in order to raise living standards) beyond providing finance, there exists today a clear consensus reflecting what might be termed negative inter-institutional policy coherence, i.e. a

83 See D. Rodrik, 'Cheerleaders Threat to World Trade', Financial Times (29 March 2007); and P. Lamy, 'Humanising Globalization', Speech by the WTO Director-General, Santiago de Chile (30 January 2006).

84 Agreement Establishing the World Trade Organization (1994), entered into force 1 January 1995, 1867 UNTS 31874 (Marrakesh Agreement) Art. III, 5. 'With a view to achieving greater coherence in global economic policy-making, the WTO shall cooperate, as appropriate, with the International Monetary Fund and with the International Bank for Reconstruction and Development and its affiliated agencies.'

85 n 41 above, 31 .

86 ibid. 
unified approach among international economic organisations to economic growth strategies that limits scope for diversity in both international and national policies, models which may serve to lift the world's poorest out of poverty in a manner more consistent with universal human rights standards and objectives. ${ }^{8}$ As a recent World Bank World Development Report notes:

[M]ost policy advice given to poor countries over the last several decades including by the World Bank - has emphasized the advantages of participating in the global economy. But global markets are far from equitable, and the rules governing their functioning have a disproportionately negative effect on developing countries. These rules are the outcome of complex negotiating processes in which developing countries have less voice. ${ }^{89}$

Awareness of the importance of international policy coherence that has affluent and powerful states better cross-fertilising their various international legal obligations has become an important part of international discourse. ${ }^{90}$ It centres on requirements, for example, that human rights-based bilateral development cooperation is not undermined by the same government's trade policies; that intellectual property rules as formulated and applied are not counterproductive to the achievement of the MDGs and related human rights obligations in the areas of reducing hunger (access to food and food security), achieving universal primary education (access to information and knowledge), combating HIV/AIDS and other diseases (access to medicines) and ensuring environmental sustainability (for example, protection of traditional indigenous knowledge); ${ }^{91}$ or that positions taken in the IFIs on key issues such as user fees are consistent with obligations of international cooperation regarding socio-economic rights under the relevant

${ }^{87}$ Dañino, n 17 above, [4]; IBRD Articles of Agreement, n 64 above, Art. I.

88 Rodrik lucidly contextualises the issues: 'If there is one lesson from the collapse of the $19^{\text {th }}$ century version of globalisation, it is that we cannot leave national governments powerless to respond to their citizens. The genius of the Bretton Woods system, which lasted for about three decades after the second world war, was that it achieved such a compromise. Some of the most egregious restrictions on trade flows were removed, while allowing governments freedom to run independent macroeconomic policies and erect their own versions of the welfare state. Developing countries were free to pursue their own growth strategies with limited external restraint. The world economy prospered like never before.' Rodrik, n 83 above.

89 World Bank, World Development Report 2006, n 17 above, 16.

90 Sweden reports that its policy for development cooperation ' ... was not only aiming to empower partner countries with increased budget support but was also promoting overall coherence among policies within its own boundaries as well as in the recipient countries with a view to contribute to the promotion and protection of human rights both domestically and internationally.' Report of the UN HighLevel Task Force on the Implementation of the Right to Development, UN Doc. E/CN.4/2005/WG.18.2, [81]; 'The task force agreed that social impact assessments provide important methodological tools to promote evidence-based policy formulation by including distributional and social effects in the ex ante analysis of policy reforms and agreements. It was potentially a useful instrument in bringing about policy coherence at both national and international levels and in promoting adherence to human rights standards.' (At [4]). See also Finland's Report on the Millennium Development Goals (2004). Available at: www.undp.org.

${ }_{91}^{1}$ M. E. Salomon, Addressing Structural Obstacles and Advancing Accountability for Human Rights: A Contribution of the Right to Development to MDG8, Submission to the $2^{\text {nd }}$ session of the UN High-Level Task Force on the Right to Development (November 2005) 7. Available at www.ohchr.org/english/issues/development /taskforce.htm. 
human rights treaties. ${ }^{92}$ But it is difficult to reconcile what would seem to be competing tendencies. On the one hand, we can point to some efforts to advance foreign policy agendas that properly give effect to legal human rights obligations and that are sensitive to the fact that the protection and promotion of human rights are the first responsibility of governments. ${ }^{93}$ All the while, however, the institutions over which those same states hold sway are committed - in policies that apply to developing countries that is - to a particular free market ideology that may not be sensitive or conducive to advancing the basic human rights of all in those countries.

Social and economic policies that were critical to the development of poor countries in the $19^{\text {th }}$ and $20^{\text {th }}$ centuries - countries that nowadays constitute the Organisation for Economic Co-operation and Development (OECD) - are deemed heterodox for today's poor countries. ${ }^{94}$ For example, developed states and not only those that subscribe to a model of social democracy - would not dream of cutting back on public spending at home to anywhere near what the IFIs advance as suitable economic policies in developing countries, as a recent study that draws lessons from the OECD for low-income countries regarding the right to social security has vividly shown. ${ }^{95}$ Notably, when they were developing, '[c]ountries like Germany, England and the United States were not subject to the domination of much more powerful external governments, agencies and corporations'. ${ }^{96}$ In a world where all states rely on the same global environment for their enrichment and thus for the satisfaction of their needs, rich countries effectively control the policies that drive the international economic order (largely through a select number of institutions), suggesting that what we have is a case of

92 A recent report by the Special Rapporteur on the Right to Health draws attention to the fact that national and international human rights law should be 'consistently and coherently applied across all relevant national and international policymaking processes' and while commending Sweden on its foreign policy in this area, announces his plans to pursue these matters by meeting with those executive directors who represent Sweden's interests in the World Bank and IMF. P. Hunt, Report of the Special Rapporteur on the Right to the Highest Attainable Standard of Physical and Mental Healtb: Mission to Sweden, UN Doc. A/HRC/4/28/Add.2 (2007) [92-95].

${ }_{93}$ UN World Conference on Human Rights, Vienna Declaration and Programme of Action (1993), UN Doc A/CONF.157/23 Part I, Art. 1.

94 'In more than three decades economic development policies advocated by the international financial agencies and leading governments have not incorporated sufficient information and direction about the course of corresponding, not to say consequential, social development. Policies designed to establish and invigorate universal public social services and social security payments came to be treated as aberrations of the past rather than as institutions as necessary to the future as to the past. Attempts to restrain and roll back social security were made with too little understanding of the accumulating historical impetus in all OECD countries of its elaborate institutions and multiple functions.' P. Townsend, The Right to Social Security and National Development: Lessons from OECD Experience for Low-Income Countries, Discussion Paper 18 (Geneva, International Labour Organization, 2007) vii.

95 In aiming to reduce poverty, establish basic social services and meet individual adversity, OECD countries have come to spend an average of ... more than a fifth (20.9 percent) on public social services and social security, excluding education.... The principal anti-poverty strategy for developing countries advised by the North will have to be changed. ... The dominant Washington consensus has been to argue for a reduction in the size of the state — reducing public expenditure, extending private ownership and management and de-regulating rules about business, trade and labour conditions. This was to apply to rich and not only poor countries. But the starting-points have been poles apart, and have been getting wider.' ibid, viii and 37.

96 ibid, ix. 
the wolf watching the sheep. Are we to be surprised that the policies these institutions have long advanced, such as the opening of developing country markets (while protecting their own) ${ }^{97}$ and the privatisation of public services, may not serve those developing countries well, while benefiting the developed countries, including through the enrichment of their private sectors?98 Writing on international trade, the UNDP affirms in its 2005 Human Development Report that within the existing rules-based multilateral system 'costs and benefits have been unevenly distributed across and within countries, perpetuating a pattern of globalization that builds prosperity for some amid mass poverty and deepening inequality for others'. ${ }^{99}$ The report concludes that the rules arranged to benefit developed countries do so at the cost of impoverishing the people in low-income countries and are based on a foundation of 'hypocrisy and double standards'. ${ }^{100}$

In a manner most pronounced since the fall of the Soviet Union, the World Bank and IMF have 'collaborated' to advance a particular economic agenda centred on the neo-liberal interests of integrating and deregulating markets globally. This model has not served all equally and those states most profoundly affected by the collateral ills of economic globalisation have been, and continue to be, those least able to influence its direction, shape and implementation. The extent and persistence of poverty in developing countries cannot thereby be considered distinct from the influence exercised by the World Bank and IMF as part of the global triumvirate - along with the WTO - of international economic governance. Disaggregated into its component parts, poverty reflects a range of violated human rights and the violation of many human rights is, in turn, a cause of poverty. In considering the impact of IFI policies on human rights in recipient countries, attention is required to both the repercussions on the exercise of specific rights, as well as to the success or failure in reducing income poverty among the poorest.

\section{LEGAL BASES AND AVENUES FOR HUMAN RIGHTS ACCOUNTABILITY}

Dubiously, wealth is the single most important criterion for conferring political

\footnotetext{
${ }^{97}$ Developed countries protect their markets at a loss to developing countries of US $\$ 700$ billion annually in export revenues. T. W. Pogge, “Assisting” the Global Poor', in D. K. Chatterjee (ed), The Ethics of Assistance: Morality and the Distant Needy (Cambridge: Cambridge University Press, 2004) 275. Protection comes in the form of tariffs, quotas, anti-dumping duties and subsidies to domestic producers. See, further, UNDP, Human Development Report 2005: International Cooperation at a Crossroads (Oxford: Oxford University Press, 2005) Ch. 4, 126-132.

98 Transnational corporations account for over $70 \%$ of world trade, form 51 of the world's 100 largest economies, and of the 200 largest TNCs none maintains headquarters outside of North America, Europe, Japan or South Korea. M. B. Steger, Globalization: A Very Short Introduction (Oxford: Oxford University Press, 2003) 48-49.

${ }^{99}$ UNDP, n 97 above, 113.

100 ibid.
} 
power in international economic decision-making. As Reddy points out, 'countries have been perceived as having a "larger stake" in world trade when they have accounted for a larger share or volume of world trade - typically, richer countries - not countries that had a larger stake in the sense of having, for example, larger numbers of persons who would potentially be affected'. ${ }^{101}$ Within the IFIs, voting is weighted based on the percentage of shares a member country holds. Each member country is assigned a quota, based broadly on its relative size in the world economy. A member's quota determines its maximum financial commitment to the IFI and its voting power. The largest shares are held by the US, at 16.4 percent of the vote in the World Bank (IBRD) (17.08 percent in the IMF), followed by Japan, Germany, the United Kingdom and France. ${ }^{102}$ Together, these five members control approximately 40 percent of the voting power on the Board of Directors and each has one Executive Director on the Board to represent it. By contrast, 26 African countries have a combined voting power of 1.99 percent and are represented by one Executive Director, with another group of 22 African countries sharing an Executive Director and exercising a combined voting power of 3.41 percent. ${ }^{103}$ This Board of Directors, which represents the Bank's full membership with power formally allocated as above, meets regularly to discuss and approve World Bank loans and policies. Added to this massive variation in executive decision-making clout is the fact that IFI decisions extend exclusively to those member countries that make use of their financing services. As becomes evident, the power differential between rich member states and the poorer and less influential states is considerable, not least since industrialised countries no longer depend on the Bank or the Fund. The upshot is, as Wade concludes, that they set and advance policies that will never apply to them, giving 'them scope for opportunism and carelessness in the conditions they require others to meet'. ${ }^{104}$ Elsewhere, claims have been made that this system of governance also serves to see favoured those developing countries that advance the geopolitical interests of the Bank's powerful shareholder governments, without mediating the conflict of interest whereby rich countries might attempt to use their positions to advance their commercial interests. ${ }^{105}$

Accountability for the exercise of this power and any ensuing negative effects of IFI policy advice, including via conditionality, on the exercise of socioeconomic rights and on poverty reduction in developing countries is clearly overdue. Regarding human rights violations, means of providing for accountability under international law have traditionally been hindered by the argument that, as international legal persons, international financial institutions (i.e. international

\footnotetext{
101 S. Reddy, Assessing the Complexities of the World Trading System, Panel, International Trade: What does Justice Demand? Carnegie Council for Ethics in International Affairs (April 2006). Available at www.cceia.org.

102 World Bank, World Development Report 2006, n 17 above, 66-67.

103 The former group has a combined voting power of $3.76 \%$ in the IDA, and the latter $4.58 \%$. 104 n 11 above, 109.

105 N. Woods, What Kind of Banker does the World Need? Public lecture, London School of Economics, 4 May 2005. Notes on file with author.
} 
organisations) are not bound by human rights treaties and that customary international law, to which they are bound, does not as yet include socio-economic rights. ${ }^{106}$ In response to the latter point, it is increasingly difficult to sustain the argument that there does not exist a general principle of international law to respect and observe human rights in the main, which today would undoubtedly include basic socio-economic rights. ${ }^{107}$ An appreciation that there are fundamental rules regarding respect of the human person and thus the protection of human rights, has, since the adoption of the UN Charter and the subsequent elaboration of human rights, entered into the body of customary international law, imposing negative obligations on all participants in the international legal system capable of impacting on their exercise.

In response to the former point (that IFIs as legal persons are not bound by human rights treaties), we are witnessing the first steps towards establishing the direct accountability of international organisations brought about by having them ratify human rights treaties. As De Schutter has rightly remarked, though, it would be a faulty approach to have as a condition of joining a human rights treaty that the organisation has competence in the area of human rights, as is the case for example with regard to the European Community and the recently adopted UN Convention on Persons with Disabilities; ${ }^{108}$ human rights treaties can and should establish respect for human rights regardless of the area in which a given organisation is mandated to work - the obligation in that case being negative and thus requiring that the international organisation respect the given rights in any areas over which it exercises competence. ${ }^{109}$ In principle, the World Bank and IMF could be eligible for ratification of the International Covenant on Economic, Social and Cultural Rights and the International Covenant on Civil and Political Rights ${ }^{110}$ on the basis of both approaches. On the first, as organisations with implied competences in the area of human rights: the World Bank is by its own admission involved in human rights through its development and poverty reduction mandate, as is the IMF given its involvement in poverty reduction and the PRSP and MDG processes. On the second approach, the IFIs would accede to the Covenants establishing, at a minimum, negative obligations to respect their

\footnotetext{
106 Gianviti, n 9 above, 118 et seq. See generally, S. I. Skogly, The Human Rights Obligations of the World Bank and International Monetary Fund (London: Cavendish Publishing, 2001).

107 On a contemporary legal doctrine of basic universal rights which today includes socio-economic rights, see $\mathrm{n} 25$ above. On the theory of human rights and United Nations doctrine requiring equal recognition of socio-economic rights, see also B. Simma and P. Alston, 'The Sources of Human Rights Law: Custom, Jus Cogens, and General Principles' (1988-89) 12 Australian Yearbook of International Law 95.

108 UN Convention on the Rights of Persons with Disabilities and Optional Protocol, GA res. A/RES/61/106 adopted 13 December 2006, Arts. 44 and 12 respectively.

109 O. De Schutter, 'Human Rights Accountability of International Organizations' conference address, Accountability for Human Rights Violations of International Organizations (Brussels, March 2007). 'As international legal persons, international organisations have the capacity to voluntarily enter into treaties to the extent that the treaties specifically accept international organisations as parties, and the rules of the organisation do not prohibit such a capacity'. H.G. Schermers and N.M. Blokker, International Institutional Law: Unity within Diversity (The Hague: Martinus Nijhoff, 3rd Edn., 1995), as referenced in Skogly, n 106 above, 81 .

110 International Covenant on Civil and Political Rights (1966), entered into force 23 March 1976, GA res. A/RES/2200A (XXI), 999 UNTS 171.
} 
precepts in the exercise of all areas of their respective mandates where they might impact on them. ${ }^{111}$

The work of the recently established UN High-Level Task Force on the Right to Development is notable for its mandate to apply human rights standards to international organisations. The Task Force is a new international expert body charged with scrutinising the human rights performance of, inter alia, international organisations by evaluating, from the perspective of the human right to development, the 'partnerships' between international organisations and developing countries. Reflecting on the possibility of evaluating a forthcoming World Bank plan for Africa, ${ }^{112}$ the Task Force noted that:

Given the preponderant role of the World Bank in the development of Africa and the influence of its thinking and operations on the donor community at large, its partnership should be critically scrutinized. Accordingly, the Bank should therefore be invited by the Working Group [on the Right to Development] to allow the African Action Plan and its partnerships with governments of Sub-Saharan African to be evaluated against the criteria on the right to development. ${ }^{113}$

A proposal was also put forward by the European Union (EU) that the Partnership Agreement between the EU and African, Caribbean and Pacific (ACP) states (the Cotonou Agreement) be subject to evaluation against the right to development criteria for global partnerships for development. ${ }^{114}$ The latter partnership is to be evaluated at the next session of the Task Force by decision of the intergovernmental UN Working Group on the Right to Development. ${ }^{115}$ These developments reflect not only progress in providing for a system of international human rights monitoring of international organisations and the impact of their conduct on poverty-related human rights violations, but indicate a shift towards acceptance of this aforementioned doctrine of basic universal rights owed to all, which spares no international actor from possessing - at a minimum negative obligations to refrain from doing violence to human rights. This mechanism, aimed at furthering the human rights accountability of international actors, reflects one attempt to address an unsustainable gap in the current system of human rights procedural safeguards.

\footnotetext{
111 Being party to the ICCPR would require, for example, IFI information disclosure policies that comply with obligations to seek and receive information (Art. 19(2)), addressing concerns that the Information Disclosure Policy at the Bank does not remedy the fact that meetings of the Board of Directors are held in secret, with limited information provided in the transcripts available. The result is that citizens have no way of knowing how they are being represented (and whether the human rights obligations of member states are being honoured). See Saul $n 9$ above, 8-9.

112 Report of the High-Level Task. Force on the Implementation of the Right to Development ( $3^{\text {rd }}$ session, 2007) UN Doc. A/HRC/4/WG.2/TF/2, [86-87 and 92].

113 ibid, [87].

114 ibid, [15 and 92].

115 Report of the Open-ended Working Group on the Right to Development ( $8^{\text {th }}$ session, 2007) UN Doc. A/HRC/4/WG.2/2, [55]; Human Rights Council res. 4/4 (2007) on the Right to Development.
} 
Based on the assessments of both the World Bank and the IMF referred to in the first section, it is clear that there are concerns as to the scale and speed with which poverty itself is being reduced and that increases in growth have not translated into a reduction in poverty in the poorest countries. It is also apparent that the IFIs - despite certain discernible evolutions in approach - largely embrace a particular neo-liberal economic model with alternative approaches having little influence and ideological preferences being retained at all costs. ${ }^{116}$ In the second section we saw the degree to which IFIs retain power in borrowing countries, yet the quality of the policy advice and the repercussions of conditions attached to World Bank and IMF funds on the exercise of human rights, including those related to poverty reduction, give rise to no meaningful form of accountability. Indeed, the IFIs are not only immune from responsibility for what might be deemed negligence with regard to their advice but damage tends to increase the importance of the IFIs by requiring a new loan to repair it, creating perverse incentives. ${ }^{117}$ Raffer explains that the complete absence of a system of financial accountability via liability and tort laws, which is essential to the proper functioning of all financial actors and ensures more careful work, is unique to the area of development cooperation, 'the last sphere where damage can be inflicted with impunity and even with financial gain'. ${ }^{118}$ The result is that developing countries and the poor within those countries are left with no protection against negligently or even wilfully inflicted damages, including where the IFIs failed to exercise their duty of care. Just as it is anomalous that so far no international forum is being used or has been established to sue the IFIs for negligent advice, it cannot be long sustained that human rights claims cannot be brought against IFIs in order to provide compensation to victims of human rights violations, and to stimulate incentives for greater care to be exercised in future. While the IFIs' Articles of Agreement provide some scope for actions to be brought against the organisations in the courts of member states, ${ }^{119}$ the material fact in determining whether immunity from domestic jurisdiction is permissible under a human rights treaty may be whether applicants have available to them reasonable alternative means (be it an independent system for the settlement of disputes within the organisation itself or external to it) to protect effectively their rights under a given human rights treaty. ${ }^{120}$

Turning to the issue of the accountability of individual industrialised member states with regards to the actions of the Bank and Fund, possibilities include using

\footnotetext{
116 See also coverage of the IFIs' handling of the Asian financial crisis, in Raffer, $\mathrm{n} 3$ above, 65.

117 ibid, 63, 77.

118 ibid, 64.

${ }^{119}$ It is feasible for actions to be brought against the World Bank in a court of competent jurisdiction in the territories of member states in which the Bank has offices, appointed agents for the purpose of accepting services or notice of process, or has issued or guaranteed securities (IBRD Articles of Agreement, n 64 above, Art. VII, Section 3; IDA Articles of Agreement, n 64 above, Art. VIII, Section 3; IFC Articles of Agreement, n 64 above, Art. VI, Section 3). The IMF would have to waive its immunity but is empowered to do so (IMF Articles of Agreement, n 65 above, Art. IX, Section 3).

120 Beer and Regan v Germany, ECtHR Application no. 28934/95, Grand Chamber judgment of 18 Feb. 1999, [58].
} 
judicial review of executive decisions of the state organ responsible for directing the vote of the Executive Directors on the Board (such as the UK Department for International Development (DFID) or Treasury), based on their compliance with national human rights legislation. ${ }^{121}$ This legal avenue for establishing the accountability of powerful donor states in the exercise of their executive decisions with impact abroad echoes lessons highlighted by the Pergan Dam case of 1995. Here the UK High Court quashed a grant of $£^{2} 200$ million which had been authorised under the Overseas Development and Co-operation Act (1980) on the grounds that it did not serve 'developmental promotion purposes' as required by the Act. ${ }^{122}$ Reflecting increasing sensitivity to extraterritorial obligations is DFID's Guidance Note on the Human Rights Act (1998) - the Act incorporates domestically the European Convention on Human Rights ${ }^{123}$ - which was issued in order to advance compliance with the UK's human rights obligations in the area of development. The Guidance note warns officials that:

As a public authority, DFID is legally bound by the Human Rights Act. This means that if an act (or failure to act) by DFID, through its Ministers or staff, is incompatible with a Convention right, DFID acts unlawfully and a "human rights claim" can be brought against the Secretary of State. It is therefore important that you are aware of the Human Rights Act and can spot potential problems before they arise. ... Decisions related to our external programmes, as well as our internal arrangements, must be carefully considered from a human rights perspective. ${ }^{124}$

Executive Directors acting on behalf of the UK in the Bank and Fund are bound to comply with their national and international human rights obligations in the policies they pursue that impact on the exercise of those rights in developing countries, the approval vote cast by their representative constituting a state act and

\footnotetext{
121 n 5 above, 21.

122 Regina $\mathrm{v}$ Secretary of State for Foreign and Commonwealth Affairs, Ex parte World Development Movement Ltd (QBD) [1995] 1 Weekly Law Reports 386. It has been further reported that: 'The disquiet originally felt about the project which had been secret for years was that arms were being traded for aid'. O. Davies QC, Can Human Rights Make Aid Agencies more Accountable, Overseas Development Institute (1 January 2005). The International Development Act (2002) replaces and repeals the 1980 Act, 'reflecting in law for the first time the centrality of poverty elimination in DFID's work and ensuring future governments will not be able to use development assistance for other purposes'. Available at www.dfid.gov.uk.

123 European Convention on Human Rights (1950), entered into force 3 September 1953, European Treaty Series 005.

124 The Human Rights Act: Building a Culture of Respect for Human Rights in DFID, Guidance Note (August 2005) 2. While the extraterritorial reach of human rights treaties with jurisdictional clauses, i.e. addressing civil and political rights, is an area of ongoing legal consideration, as Wilde summarises in his study on the subject: '.. bodies representing three leading international judicial or quasi-judicial institutions monitoring the application of international legal instruments on civil and political rights - the Human Rights Committee, the Inter-American Commission, and the European Court and Commission of Human Rights - all conclude that as a matter of principle this area of international human rights law should apply extraterritorially'. R. Wilde, 'Legal "Black Hole"? Extraterritorial State Action and International Treaty Law on Civil and Political Rights' (2005) 26 Michigan Journal of International Law 797.
} 
thus subject to human rights law and the general law on state responsibility. ${ }^{125}$ Under the Human Rights Act, protected rights would include non-discriminatory access by the poor to education ${ }^{126}$ (addressing the issue of user fees, for example); non-discriminatory access by the poor to healthcare, which would potentially engage the right to respect for private and family life, the right to marry and found a family, and the prohibition of inhuman and degrading treatment ${ }^{127}$ (addressing, for example, the issue of privatisation of essential services); 128 freedom of expression (i.e. access to information on decisions taken by, for example, the Board of Directors); and indeed indirect threats to the right to life itself related to measures aimed at reducing infant mortality, malnutrition and epidemics. ${ }^{129}$ While human rights obligations do not preclude states cooperating internationally in the pursuit of other particular objectives (eg economic development, international monetary cooperation), the European Court of Human Rights has repeatedly held that the human rights responsibilities of member states continue even after the transfer of competences to international organisations. ${ }^{130}$ Furthermore,

[i]n the Court's view, State action taken in compliance with such legal obligations is justified as long as the relevant organisation is considered to protect fundamental rights, as regards both the substantive guarantees offered

\footnotetext{
${ }_{125}$ As has elsewhere been cogently argued, the international legal personalities of the Bank and Fund do not imply that decisions adopted by the organs of the international organisation can be attributed to the organisation but not to the states that participated in the organs. 'This argument fails to distinguish between the act of the State and the act of the international organization. The question is not one of attribution of the IO's act to the State, but rather of the responsibility of the State for its own act. Further, this argument [that there can be no state responsibility where there is international personality] creates a legal limbo, one where States control IOs but are immune from legal responsibility for the consequences of such control. It appears that the better approach is to recognize both the responsibility of the State for the acts of its organs, e.g. an executive director that votes to approve a project, as well as the responsibility of the IFI for the acts of its organs, e.g., a board of directors that approves a project'. International Financial Institutions and Human Rights Law, Legal Analysis by the Centre for International Environmental Law, Public Hearing, Inter-American Commission on Human Rights (127th Regular Period of Sessions) (1 March 2007) 4.

126 See generally, DFID Guidance Note, n 124 above, 8.

127 See generally, ibid.

128 A recent Policy Paper by the UK recognises the general concern around the 'social impact of privatization policies in the area of public services' and notes that there are 'examples where privatization has not benefited the poor' [4.6.]. In deciding to cease imposing privatisation as a condition of aid in 2005, the government publicly acknowledged that 'in the 1980s and 1990s donors pushed for the introduction of [privatization and trade] reforms, regardless of whether they were in the [developing] countries' best interests.' Partnerships for Poverty Reduction: Retbinking Conditionality, n 55 above, [4.5]. In 2005-6, f272 million of the UK's Gross Public Expenditure on Development was channelled through the World Bank Group (www.dfid.gov.uk/aboutdfid/statistics.asp), which does continue to impose privatisation measures. On the finding that material deprivation may constitute inhuman and degrading treatment in breach of the European Convention on Human Rights, see the UK House of Lords' landmark 'Limbuela' case, Regina $\mathrm{v}$ Secretary of State for the Home Department (Appellant) ex parte Limbuela (FC) (Respondent) and Ors (Conjoined Appeals), judgment of 3 November 2005, [2005] UKHL 66.

129 See Human Rights Committee, General Comment No. 6 (Article 6) The Right to Life (1982), reprinted in UN Doc. HRI/GEN/1/Rev.7 (2004) [5].

130 Matthens v United Kingdom, ECtHR Application No. 24833/94, Grand Chamber judgment of 18 February 1999, [29, 32 and 34]; Waite and Kennedy v Germany, ECtHR Application no. 26083/94, Grand Chamber judgment of 18 February 1999, [67]; Bosphorus Airways v Ireland, ECtHR Application No. 45036/98, Grand Chamber judgment of 30 June 2005, [152-156].
} 
and the mechanisms controlling their observance, in a manner which can be considered at least equivalent to that for which the Convention provides. ${ }^{131}$

Under the equivalent protection doctrine, state responsibility for state acts within IFI organs would require them to ensure that decisions regarding policy-based financing and accountability mechanisms, as well as project-specific operational policies and inspection mechanisms, offer protection that is 'comparable' to the human rights standards by which a given member state is bound. It follows, moreover, that human rights bodies can evaluate whether an IFI has adequate and effective mechanisms suitable to ensuring the protection of human rights. ${ }^{132}$ Indeed, such equivalent protection provided by the organisation is required in order for there to be a presumption that the state has not departed from its human rights obligations. ${ }^{133}$ On the matter of compliance with obligations under the International Covenant on Economic, Social and Cultural Rights, that treaty explicitly includes an obligation of international assistance and cooperation (Article 2(1)), which has been interpreted by the Committee as requiring that the states parties from industrialised countries, as members of the IFIs, 'do all [they] can to ensure that the policies and decisions of the [World Bank and IMF] are in conformity with the obligations of State parties to the Covenant .... ${ }^{134}$

\section{CONCLUSION}

Both the World Bank and the IMF are nowadays engaged in development and poverty reduction. As a result, the Bank, in particular, recognises its multifaceted relationship to human rights. As this chapter has shown, it quite readily publicises that its work in many areas - from promoting the status of women to confronting corruption - contributes to the realisation of human rights. It also recognises it has a part to play in supporting the ability of states to give effect to their human rights obligations where they relate to Bank projects and policies. The third entry point into human rights identified by the Bank has human rights protection and promotion posited in their instrumental role, in this case by contributing to the making of better economic actors and improved economic development. While these developments provide important points of departure, this research has been preoccupied with a fourth factor that is all but absent from the rhetoric and practice of the IFIs: the human rights accountability of international economic

\footnotetext{
131 Bosphorus Airways v Ireland, n 130 above, [155].

132 See, n 125 above, 5.

133 See Bosphorus Airways v Ireland, n 130 above, [155-156].

134 CESCR, Concluding Observations: Belgium, UN Doc. E/C.12/1/Add.54 (2000) [31]; CESCR, Concluding Observations: Italy, UN Doc. E/C.12/1/Add.43 (2000) [20]; CESCR, Concluding Observations: United Kingdom of Great Britain and Northern Ireland, United Kingdom of Great Britain and Northern Ireland - Dependent Territories, UN Doc. E/C.12/1/Add.79 (2002) [26].
} 
actors for their own negative impact on the exercise of basic socio-economic rights of people in recipient member states.

In a challenge to the longstanding practice of the IFIs to condition their aid on the introduction of particular reforms, donors are now claiming that they will no longer support programmes that are made conditional on liberalisation or privatisation. ${ }^{135}$ These are important steps that nonetheless tell us little about bilateral or multilateral donor accountability to people in developing countries whose basic rights to water or healthcare or to an adequate standard of living may have been affected as a result of injurious externally imposed economic policies. The adoption of these foreign policy positions that reject conditionality linked to particular economic reforms intensifies the pressure now to see them translated into concrete institutional change within the IFIs, while serving to underscore the basis for the concerns articulated in this chapter. While this general trend toward acknowledging the relevance of human rights to improved economic growth represents a significant advance, it does not address the specific role of the IFIs themselves in contributing to policy-based human rights violations in developing countries, including where they fail to reduce poverty. Given their substantial influence in borrowing countries, it has become increasingly untenable that the IFIs should function without human rights responsibilities within their spheres of influence, and without accountability for the impact of their economic decisions on the exercise of human rights. While the evolving mandates of the World Bank and IMF crystallising around poverty reduction renders it increasingly apparent as to how human rights fall within their competences, the requirement that the IFIs respect human rights is not linked solely to that fact.

Contrary to the vision of the key architect of the Bretton Woods system in the 1940s, international economic governance is directed to a very considerable degree by the wealthy and powerful states. Through a band of economic institutions over which they exercise control, their ideological and economic preferences dramatically impact on the exercise of basic socio-economic rights in developing countries. Given the configuration of international economic governance today, it is baseless to conceive that the government of a poor country, on its own, can necessarily be the sole entity to account for the inability of its people, most notably the poorest, to secure their fundamental rights to an adequate standard of living, including adequate food, water, clothing and housing, and rights to health, education and social security. Today the Bank and Fund possess near universal membership, a position unique within the international development community, placing upon them a critical role at justly reconciling the

\footnotetext{
135 Partnerships for Poverty Reduction: Retbinking Conditionality, n 55 above; Soria Moria Declaration on International Policy, Norway Political Platform for a Majority Government (2005). On EU 'neutrality' regarding the ownership of public utilities and thus the need for 'closer dialogue' with the Bretton Woods institutions on the matter, see Commission of the European Communities, The Reform Of State-Owned Enterprises In Developing Countries With A Focus On Public Utilities: The Need To Assess All The Options, Communication From The Commission To The Council And European Parliament, Brussels, COM(2003) 326 final (June 2003).
} 
relationship between developing countries and governance of the international economic order.

The international human rights legal regime requires that rights be protected and secured through an accompanying system of accountability. As a complement to the primary legal framework expressing the duties of states and other actors in this field, remedies in human rights law provide this secondary theory of what duties exist when a primary duty is violated. ${ }^{136}$ Given the contemporary links between the IFIs and the exercise of socio-economic rights in poor countries, there now exists the responsibility to spell out that implication in detail through the advent of appropriate and effective means of accountability in this area of international governance, so that the basic human rights of all may be progressively realised.

136 D. Shelton, Remedies in International Human Rights Law (Oxford: Oxford University Press, 2nd ed, 2005) 7. 